\title{
Synthesis and optical properties of azobenzene-containing poly(1-alkyne)s with different spacer lengths and ring substituents
}

\author{
Shouchun Yin ${ }^{\mathrm{a}}$, Hongyao Xu ${ }^{\mathrm{a} *}$, Xinyan $\mathrm{Su}^{\mathrm{a}}$, Yachen Gao ${ }^{\mathrm{b}}$, Yinlin Song ${ }^{\mathrm{b}}$, Jacky Wing Yip Lamc, \\ Ben Zhong Tang ${ }^{\mathrm{a}, \mathrm{c}}$, Wenfang Shi ${ }^{\mathrm{d}}$ \\ ${ }^{\mathrm{a}}$ Faculty of Chemistry and Chemical Engineering and the Key Laboratory of Environment-Friendly Polymer Materials of Anhui Province, \\ Anhui University, Hefei 230039, China \\ ${ }^{\mathrm{b}}$ Department of Physics, Harbin Institute of Technology, Harbin 150001, China \\ ${ }^{\mathrm{c}}$ Department of Chemistry, Hong Kong University of Science and Technology, Clear Water Bay, Kowloon, Hong Kong, China \\ ${ }^{\mathrm{d}}$ Department of Polymer Materials and Science, University of Science and Technology of China, Hefei 230026, China
}

Received 23 May 2005; received in revised form 26 July 2005; accepted 29 July 2005

Available online 11 August 2005

\begin{abstract}
Poly(1-alkyne)s containing azobenzene pendants with different spacer lengths and ring substitutents $-\left\{\mathrm{HC}=\mathrm{C}\left[\left(\mathrm{CH}_{2}\right)_{m} \mathrm{COO}-\mathrm{C}_{6} \mathrm{H}_{4}-\mathrm{N}=\mathrm{N}-\right.\right.$ $\left.\left.\mathrm{C}_{6} \mathrm{H}_{4}-\mathrm{NO}_{2}\right]\right\}_{n}-\mathrm{P} \mathbf{1}(m) m=3,8$ and $\left.-\left\{\mathrm{HC}=\mathrm{C}\left[\left(\mathrm{CH}_{2}\right)_{m} \mathrm{COO}-\mathrm{C}_{6} \mathrm{H}_{3}-o-\mathrm{Br}-\mathrm{N}=\mathrm{N}-\mathrm{C}_{6} \mathrm{H}_{4}-\mathrm{NO}_{2}\right]\right\}_{n}-\mathrm{P} 2(m) m=3,8\right\}$ are designed and synthesized. The polymers are prepared in satisfactory yields with high molecular weights $\left(M_{\mathrm{w}}\right.$ up to $\left.3.3 \times 10^{4} \mathrm{Da}\right)$ by $[\mathrm{Rh}(\mathrm{nbd}) \mathrm{Cl}]_{2}-\mathrm{Et}{ }_{3} \mathrm{~N}$ in $\mathrm{THF}$ or dioxane. Their structures and properties are characterized and evaluated by IR, UV, NMR, TGA, nonlinear optical and optical limiting analyses. All the polymers are completely soluble in common organic solvents and lose $5 \%$ of their weights at temperatures of $\sim 270{ }^{\circ} \mathrm{C}$. The spacer length and the pendant substitutent affect the nonlinear optical and optical limiting properties of the polymers, with $\mathbf{1}(3)$ showing superior properties than its counterparts $\mathbf{1}(8)$ and 2(3) with long methylene spacers and bromide substitutents on the azobenzene pendants, respectively.
\end{abstract}

(C) 2005 Elsevier Ltd. All rights reserved.

Keywords: Functional polyacetylene; Optical limiting; The third-order nonlinear optics

\section{Introduction}

Conjugated organic materials exhibiting strong nonlinear optical properties and fast response time have attracted considerable interest in recent years because of their usages in a variety of optical devices. In particular, their applicability for optical limiters has received significant attention owing to the growing needs for protection of human eyes and optical sensors from intense laser beams [1-5]. Polyacetylene, a prototypical conjugated polymer, shows large third-order electric susceptibilities $\chi^{(3)}$ and fast response time [6]. However, its intractability and instability have significantly limited its practical applications as a specialty material. Incorporation of functional pendants into

\footnotetext{
* Corresponding author. Tel.: + 865515107342 ; fax: + 865515108203.

E-mail address: hongyaoxu@163.com (H. Xu).
}

0032-3861/\$ - see front matter (C) 2005 Elsevier Ltd. All rights reserved. doi:10.1016/j.polymer.2005.07.093 the polyacetylene structure has dramatically improved its solubility and stability and has generated substituted polyacetylenes with enhanced optical properties. Sone found that the third-order nonlinear optical coefficient of trans-poly[o-trifluoromethyl(phenylacetylene)] film prepared by Mo catalyst is about two times larger than its cis-counterpart synthesized by Rh catalyst [7]. Masuda found that substituents on the ortho-positions of the phenyl rings of poly(phenylacetylene)s [7-9] and incorporation of bulky and planar aromatic rings such as carbazole, naphthalene, or anthracene into the polyacetylene main chains [10-12] can effectively improve the third-order nonlinear optical susceptibilities of the resulting polymers. Schuling once found that the third-order nonlinear optical susceptibility $(\gamma)$ depends on $\gamma_{\mathrm{e}}^{0}$, a term related to the movement of electron, and $\beta$, the second-order nonlinear optical susceptibility [13].

Azobenzene is a well-known second-order nonlinear optical active chromophore. Polyacetylenes containing such chromophore are expected to show novel optical properties. 
Thus, in this paper, we report our recent work on the attachment of azobenzene as pendants into the poly(1alkyne) structures and present how the structural variation affects their nonlinear optical and optical limiting properties.

\section{Experimental section}

\subsection{Materials}

2,5-Norborndienerhodium(I) chloride dimer $[\mathrm{Rh}(\mathrm{nbd})$ $\mathrm{Cl}_{2}$ was purchased from Aldrich, kept under an inertatmosphere in a glove box, and used as received without further purification. 5-Hexynoic acid and 10-undecynoic acid were purchased from Tokyo Kasei (TCI). 4-Nitroaniline, phenol, 2-bromophenol, 1,3-dicyclohexylcarbodiimide (DCC), and 4-(dimethylamino)pyridine (DMAP) were purchased from Shanghai Chemical Reagent Company. Dioxane, THF, and toluene were distilled from sodium benzophenone ketyl immediately prior to use. Triethylamine was distilled from potassium hydroxide prior to use. Methanol was used to precipitate the resulting polymer products.

\subsection{Instruments}

The IR spectra were recorded as $\mathrm{KBr}$ pellets on a Nicolet $170 \mathrm{~s} \times$ spectrometer. The ${ }^{1} \mathrm{H}$ NMR spectra were recorded on an AVANCE/DMX-300 MHz Bruker NMR spectrometer using chloroform- $d$ or DMSO- $d$ as the solvent. Tetramethylsilane (TMS) or chloroform- $d$ or DMSO- $d$ was used as the internal reference for the NMR analyses. Elemental analyses were conducted using an Elemental Vario EL-III apparatus. Melting points ( $\mathrm{mp}$ ) were measured on a Yanaco micro melting point apparatus. UV spectra were recorded on a Shimadzu UV-265 spectrometer using a 1 -cm-square quartz cell; the molar absorptivities $(\varepsilon)$ of the polymers were calculated on the basis of their repeat units. Thermogravimetric analyses (TGA) of the polymers were performed on a Perkin-Elmer TGA 7 under nitrogen at a heating rate of $20^{\circ} \mathrm{C} / \mathrm{min}$. The molecular weights of the polymers were estimated by gel permeation chromatography (GPC) using a Waters Associates liquid chromatograph equipped with a Waters 510 HPLC pump, a Rheodyne $7725 \mathrm{i}$ injector with a stand kit, a set of Styragel columns (HT3, HT4, and HT6; molecular weight range $10^{2}-10^{7}$ ), a column temperature controller, a Waters 486 wavelengthtunable UV-vis detector, a Waters 410 differential refractometer, and a system DMM/scanner possessing an 8-channel scanner option. All polymer solutions were prepared in THF (ca. $2 \mathrm{mg} / \mathrm{mL}$ ) and filtered through 0.45 $\mu \mathrm{m}$ PTFE syringe-type filters before injected into the GPC system. THF was used as the eluent at a flow rate of $1.0 \mathrm{~mL} / \mathrm{min}$. The column temperature was maintained at $30^{\circ} \mathrm{C}$ and the working wavelength of the UV detector was set at $254 \mathrm{~nm}$. A set of monodisperse polystyrene standards (Waters) was used for calibration purposes.

The optical limiting properties were measured in THF solutions. Testing was performed using a frequencydoubled, Q-switched, mode-locked Continuum ns/ps Nd: YAG laser, which provides linearly polarized $8 \mathrm{~ns}$ optical pulses at $532 \mathrm{~nm}$ wavelength with a repetition of $1 \mathrm{~Hz}$. The experimental arrangement is similar to that in the literature [14]. The transverse mode of the laser pulses is nearly Gaussian. The input laser pulses were splitted into two beams by an attenuator (Newport). One was employed as reference to monitor the incident laser energy, and the other was focused onto the sample cell by using a lens with $30 \mathrm{~cm}$ focal length. The sample was positioned at the focus and housed in quartz cells with a thickness of $5 \mathrm{~mm}$. The incident and transmitted laser pulses were monitored by utilizing two energy detectors, $\mathrm{D}_{1}$ and $\mathrm{D}_{2}$ (Rjp-735 energy probes, Laser Precision).

The nonlinear optical properties of the polymers were evaluated by a $\mathrm{Z}$ scan technique using the same laser system as in the optical limiting experiment. The experimental setup can be found in the literature [15]. The input energy was $100 \mu \mathrm{J}$. The sample solution was placed in a $2 \mathrm{~mm}$ quartz cell and moved along the axis of the incident beam $(z-$ direction).

\subsection{Synthesis of the monomers}

The monomers were prepared according to the reactions shown in Scheme 1.The detailed experimental procedures are given below.

\subsubsection{4'-Nitro-4-hydroxylazobenzene (S1)}

$2.76 \mathrm{~g}(20 \mathrm{mmol})$ 4-nitroaniline was dissolved in $8 \mathrm{~mL}$ concn. hydrochloric acid. After cooling to $0{ }^{\circ} \mathrm{C}$, an ice-water solution of sodium nitrite $(1.38 \mathrm{~g}, 20 \mathrm{mmol})$ was added dropwise to the resulting solution and stirred for $30 \mathrm{~min}$. $1.97 \mathrm{~g}(21 \mathrm{mmol})$ phenol was dissolved in $15 \mathrm{~mL}$ aqueous $\mathrm{NaOH}(0.84 \mathrm{~g}, 21 \mathrm{mmol})$ solution. Then this solution was

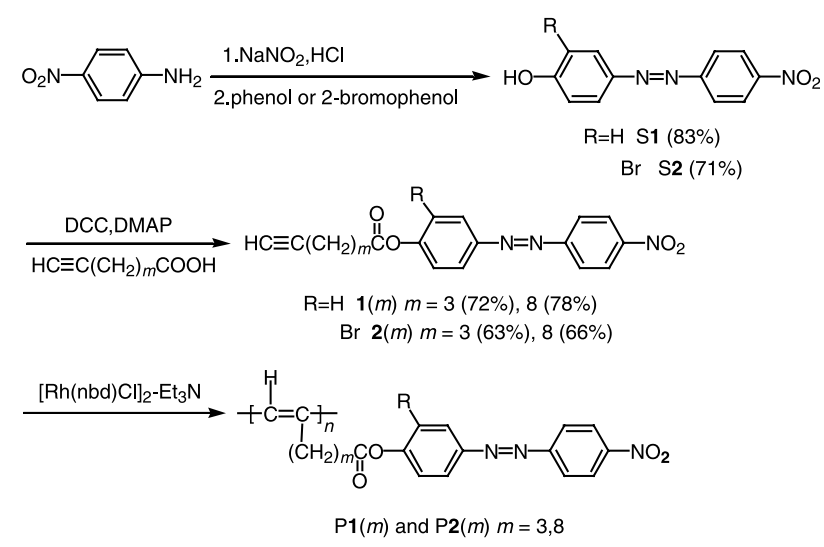

Scheme 1 
added to $400 \mathrm{~mL}$ an aqueous buffer solution of $1 \mathrm{NH}_{4} \mathrm{Cl}-$ $\mathrm{NH}_{3} \cdot \mathrm{H}_{2} \mathrm{O}(\mathrm{pH} \sim 9)$. The so-formed diazonium chloride solution was added to the buffer solution and stirred for $2 \mathrm{~h}$ at $0 \sim 5{ }^{\circ} \mathrm{C}$. The mixture was adjusted to $\mathrm{pH} \sim 6$ using aqueous $\mathrm{HCl}$ solution and the resulting precipitate was filtered, rinsed with water twice. The crude product was recrystallized from ethanol twice to give a red powder in $83 \%$ yield $(4.03 \mathrm{~g})$. IR $(\mathrm{KBr}), \nu\left(\mathrm{cm}^{-1}\right): 3416(\mathrm{OH}), 1593$ (Ar), 1508, 1335, $855\left(\mathrm{NO}_{2}\right) .{ }^{1} \mathrm{H}$ NMR $(300 \mathrm{MHz}, \mathrm{DMSO}-$ $\left.d_{6}\right), \delta(\mathrm{ppm}): 8.37\left(2 \mathrm{H}, \mathrm{d}, \mathrm{H}^{9}\right), 7.99\left(2 \mathrm{H}, \mathrm{d}, J=8.7 \mathrm{~Hz}, \mathrm{H}^{8}\right)$, $7.94\left(2 \mathrm{H}, \mathrm{d}, \mathrm{H}^{6}\right), 6.98\left(2 \mathrm{H}, \mathrm{d}, J=8.5 \mathrm{~Hz}, \mathrm{H}^{5}\right), 5.34(1 \mathrm{H}, \mathrm{s}$, $\mathrm{OH}$ ) (for the numbering of the phenyl protons, Fig. 2).

\subsubsection{4'-Nitro-3-bromo-4-hydroxylazobenzene (S2)}

This compound was prepared by coupling reaction of 4-nitroaniline with 2-bromophenol, using procedures as described above. Red power; yield 71\%. IR ( $\mathrm{KBr}), \nu$ $\left(\mathrm{cm}^{-1}\right)$ : $3439(\mathrm{OH}), 1592(\mathrm{Ar}), 1520,1343,857\left(\mathrm{NO}_{2}\right) .{ }^{1} \mathrm{H}$ NMR $\left(300 \mathrm{MHz}\right.$, DMSO- $\left.d_{6}\right), \delta(\mathrm{ppm}): 8.37\left(2 \mathrm{H}, \mathrm{d}, \mathrm{H}^{9}\right)$, $8.18\left(1 \mathrm{H}, \mathrm{s}, \mathrm{H}^{7}\right), 7.99\left(2 \mathrm{H}, \mathrm{d}, J=8.8 \mathrm{~Hz}, \mathrm{H}^{8}\right), 7.94\left(1 \mathrm{H}, \mathrm{d}, \mathrm{H}^{6}\right)$, $7.17\left(1 \mathrm{H}, \mathrm{d}, J=8.6 \mathrm{~Hz}, \mathrm{H}^{5}\right), 6.47(1 \mathrm{H}, \mathrm{s}, \mathrm{OH})$.

\subsubsection{5-\{[(4'-Nitro-4-azobenzene)oxy]carbonyl $\}$-1-pentyne 1(3)}

5-Hexynoic acid $(1.23 \mathrm{~g}, 11 \mathrm{mmol}), 4^{\prime}$-nitro-4-hydroxylazobenzene $(2.43 \mathrm{~g}, 10 \mathrm{mmol})$, and DMAP $(12 \mathrm{mg}$, $0.1 \mathrm{mmol})$ were dissolved in dry THF $(200 \mathrm{~mL})$ in a $500 \mathrm{~mL}$ flask under nitrogen. The solution was cooled to $0{ }^{\circ} \mathrm{C}$ with an ice-water bath, to which $2.2 \mathrm{~g} \mathrm{DCC}(11 \mathrm{mmol})$ in $50 \mathrm{~mL}$ THF was added with stirring via a dropping funnel with a pressure-equalization arm. The reaction mixture was stirred at room temperature for $72 \mathrm{~h}$. After filtering out the crystalline urea by-product, the solution was concentrated by a rotary evaporator. The crude product was purified by column chromatography $\left(\mathrm{Al}_{2} \mathrm{O}_{3}\right.$, ethyl acetate: Petroleum ether $=1: 3$ as eluent) and finally recrystallized from acetone-ethanol to yield $2.42 \mathrm{~g}(72 \%)$ of red crystals. IR $(\mathrm{KBr}), \nu\left(\mathrm{cm}^{-1}\right): 3273(\equiv \mathrm{C}-\mathrm{H}), 2933,2848\left(\mathrm{CH}_{2}\right), 2113$ $(\mathrm{C} \equiv \mathrm{C}), 1746(\mathrm{C}=\mathrm{O}), 1595(\mathrm{Ar}), 1519,1349,860\left(\mathrm{NO}_{2}\right) .{ }^{1} \mathrm{H}$ NMR (300 MHz, $\left.\mathrm{CDCl}_{3}\right), \delta(\mathrm{ppm}): 8.39\left(2 \mathrm{H}, \mathrm{d}, \mathrm{H}^{9}\right), 8.02$ $\left(2 \mathrm{H}, \mathrm{d}, J=8.9 \mathrm{~Hz}, \mathrm{H}^{6}\right), 8.01\left(2 \mathrm{H}, \mathrm{d}, \mathrm{H}^{8}\right), 7.30(2 \mathrm{H}, \mathrm{d}, J=$ $\left.8.2 \mathrm{~Hz}, \mathrm{H}^{5}\right), 2.78\left(2 \mathrm{H}, \mathrm{t}, J=7.3 \mathrm{~Hz}, \equiv \mathrm{CCH}_{2} \mathrm{CH}_{2} \mathrm{CH}_{2}\right), 2.39$ $\left(2 \mathrm{H}, \mathrm{t}, \equiv \mathrm{CCH}_{2} \mathrm{CH}_{2}\right), 2.01\left(2 \mathrm{H}, \mathrm{td}, J=7.1 \mathrm{~Hz}, \equiv \mathrm{CCH}_{2} \mathrm{CH}_{2}\right)$, $1.96(1 \mathrm{H}, \mathrm{s}, \mathrm{HC} \equiv) . T_{\mathrm{m}}=100-101^{\circ} \mathrm{C}$. Elem. Anal. Calcd for $\mathrm{C}_{18} \mathrm{H}_{15} \mathrm{~N}_{3} \mathrm{O}_{4}$ : C 64.09; H 4.45; N 12.46. Found: $\mathrm{C} 64.15 ; \mathrm{H}$ $4.48 ; \mathrm{N} 12.38$.

\subsubsection{0-\{[(4'-Nitro-4-azobenzene $)$ oxy $]$ carbonyl\}-1-decyne 1(8)}

Monomer 1(8) was prepared in a similar fashion. Yellow solid; yield 78\%. IR (KBr), $\nu\left(\mathrm{cm}^{-1}\right): 3276(\equiv \mathrm{C}-\mathrm{H}), 2930$, $2856\left(\mathrm{CH}_{2}\right), 2115(\mathrm{C} \equiv \mathrm{C}), 1760(\mathrm{C}=\mathrm{O}), 1585(\mathrm{Ar}), 1522$, 1352, $858\left(\mathrm{NO}_{2}\right) .{ }^{1} \mathrm{H}$ NMR $\left(300 \mathrm{MHz}, \mathrm{CDCl}_{3}\right), \delta(\mathrm{ppm})$ : $8.39\left(2 \mathrm{H}, \mathrm{d}, \mathrm{H}^{9}\right), 8.03\left(2 \mathrm{H}, \mathrm{d}, \mathrm{H}^{6}\right), 8.01(2 \mathrm{H}, \mathrm{d}, J=8.9 \mathrm{~Hz}$, $\left.\mathrm{H}^{8}\right), 7.29\left(2 \mathrm{H}, \mathrm{d}, J=8.3 \mathrm{~Hz}, \mathrm{H}^{5}\right), 2.61[2 \mathrm{H}, \mathrm{t}, J=7.4 \mathrm{~Hz}$, $\left.\equiv \mathrm{CCH}_{2} \mathrm{CH}_{2}\left(\mathrm{CH}_{2}\right)_{4} \mathrm{CH}_{2} \mathrm{CH}_{2}\right], 2.20\left(2 \mathrm{H}, \mathrm{td}, \equiv \mathrm{CCH}_{2} \mathrm{CH}_{2}\right)$,
$1.95(1 \mathrm{H}, \mathrm{s}, \mathrm{HC} \equiv), 1.78\left[2 \mathrm{H}, \mathrm{tt}, \equiv \mathrm{CCH}_{2} \mathrm{CH}_{2}\left(\mathrm{CH}_{2}\right)_{4} \mathrm{CH}_{2}\right]$, $1.54\left(2 \mathrm{H}, \mathrm{tt}, J=7.5 \mathrm{~Hz}, \equiv \mathrm{CCH}_{2} \mathrm{CH}_{2}\right), 1.38[8 \mathrm{H}$, tt, $\left.\equiv \mathrm{CCH}_{2} \mathrm{CH}_{2}\left(\mathrm{CH}_{2}\right)_{4}\right] . T_{\mathrm{m}}=94-95^{\circ} \mathrm{C}$. Elem. Anal. Calcd for $\mathrm{C}_{23} \mathrm{H}_{25} \mathrm{~N}_{3} \mathrm{O}_{4}$ : C 67.81; $\mathrm{H}$ 6.14; N 10.32. Found: C 67.75 ; H 6.11; N 10.36 .

\subsubsection{5-\{[(4'-Nitro-3-bromo-4-azobenzene $)$ oxy $]$ carbonyl $\}$ - 1-pentyne 2(3)}

It was prepared by reaction of $4^{\prime}$-nitro-3-bromo-4hydroxylazobenzene with 5-hexynoic acid, using the procedures for the synthesis of $\mathbf{1}(3)$. Red crystals; yield 63\%. IR (KBr), $\nu\left(\mathrm{cm}^{-1}\right): 3300(\equiv \mathrm{C}-\mathrm{H}), 2933,2857\left(\mathrm{CH}_{2}\right)$, $2120(\mathrm{C} \equiv \mathrm{C}), 1756(\mathrm{C}=\mathrm{O}), 1586(\mathrm{Ar}), 1518,1350,858$ $\left(\mathrm{NO}_{2}\right) .{ }^{1} \mathrm{H}$ NMR $\left(300 \mathrm{MHz}, \mathrm{CDCl}_{3}\right), \delta(\mathrm{ppm}): 8.38(2 \mathrm{H}, \mathrm{d}$, $\left.\mathrm{H}^{9}\right), 8.22\left(1 \mathrm{H}, \mathrm{s}, \mathrm{H}^{7}\right), 8.02\left(2 \mathrm{H}, \mathrm{d}, J=8.9 \mathrm{~Hz}, \mathrm{H}^{8}\right), 7.99(1 \mathrm{H}$, d, $\left.\mathrm{H}^{6}\right), 7.34\left(2 \mathrm{H}, \mathrm{d}, J=8.6 \mathrm{~Hz}, \mathrm{H}^{5}\right), 2.84(2 \mathrm{H}, \mathrm{t}, J=7.4 \mathrm{~Hz}$, $\left.\equiv \mathrm{CCH}_{2} \mathrm{CH}_{2} \mathrm{CH}_{2}\right), 2.41\left(2 \mathrm{H}\right.$, td, $\left.\equiv \mathrm{CCH}_{2} \mathrm{CH}_{2}\right), 2.05(1 \mathrm{H}, \mathrm{s}$, $\mathrm{HC} \equiv), 2.04\left(2 \mathrm{H}, \mathrm{t}, J=7.1 \mathrm{~Hz}, \equiv \mathrm{CCH}_{2} \mathrm{CH}_{2}\right) . T_{\mathrm{m}}=104$ $105{ }^{\circ} \mathrm{C}$. Elem. Anal. Calcd for $\mathrm{C}_{18} \mathrm{H}_{14} \mathrm{BrN}_{3} \mathrm{O}_{4}$ : C 51.92; H 3.37; N 10.10. Found: C 51.91; H 3.32; N 10.23.

\subsubsection{0-\{[(4'-Nitro-3-bromo-4-azobenzene $)$ oxy $]$ carbo- nyl\}-1-decyne 2(8)}

It was prepared by esterification of 4'-nitro-3-bromo-4hydroxylazobenzene with 10-undecynoic acid, again using DCC as dehydrating agent. Yellow solid; yield 66\%. IR (KBr), $\nu\left(\mathrm{cm}^{-1}\right): 3303(\equiv \mathrm{C}-\mathrm{H}), 2931,2853\left(\mathrm{CH}_{2}\right), 2116$ $(\mathrm{C} \equiv \mathrm{C}), 1757(\mathrm{C}=\mathrm{O}), 1596(\mathrm{Ar}), 1530,1346,859\left(\mathrm{NO}_{2}\right) .{ }^{1} \mathrm{H}$ NMR $\left(300 \mathrm{MHz}, \mathrm{CDCl}_{3}\right), \delta(\mathrm{ppm}): 8.39\left(2 \mathrm{H}, \mathrm{d}, \mathrm{H}^{9}\right), 8.24$ $\left(1 \mathrm{H}, \mathrm{d}, \mathrm{H}^{7}\right), 8.04\left(2 \mathrm{H}, \mathrm{d}, J=8.8 \mathrm{~Hz}, \mathrm{H}^{8}\right), 7.99\left(1 \mathrm{H}, \mathrm{d}, \mathrm{H}^{6}\right)$, $7.34\left(1 \mathrm{H}, \mathrm{d}, J=8.5 \mathrm{~Hz}, \mathrm{H}^{5}\right), 2.67[2 \mathrm{H}, \mathrm{t}, J=7.5 \mathrm{~Hz}$, $\left.\equiv \mathrm{CCH}_{2} \mathrm{CH}_{2}\left(\mathrm{CH}_{2}\right)_{4} \mathrm{CH}_{2} \mathrm{CH}_{2}\right], 2.20\left(2 \mathrm{H}, \mathrm{td}, \equiv \mathrm{CCH}_{2} \mathrm{CH}_{2}\right)$, $1.95(1 \mathrm{H}, \mathrm{s}, \mathrm{HC} \equiv), 1.82\left[2 \mathrm{H}, \mathrm{tt}, \equiv \mathrm{CCH}_{2} \mathrm{CH}_{2}\left(\mathrm{CH}_{2}\right)_{4} \mathrm{CH}_{2}\right]$, $1.53\left(2 \mathrm{H}, \mathrm{tt}, J=7.5 \mathrm{~Hz}, \equiv \mathrm{CCH}_{2} \mathrm{CH}_{2}\right), 1.34[8 \mathrm{H}, \mathrm{tt}$, $\left.\equiv \mathrm{CCH}_{2} \mathrm{CH}_{2}\left(\mathrm{CH}_{2}\right)_{4}\right] . T_{\mathrm{m}}=98-99^{\circ} \mathrm{C}$. Elem. Anal. Calcd for $\mathrm{C}_{23} \mathrm{H}_{24} \mathrm{BrN}_{3} \mathrm{O}_{4}$ : $\mathrm{C} 56.79 ; \mathrm{H} 4.94 ; \mathrm{N}$ 8.64. Found: $\mathrm{C}$ $56.84 ; \mathrm{H} 4.98 ; \mathrm{N} 8.59$.

\subsection{Polymerization}

All the polymerization reactions and manipulations were performed under pre-purified nitrogen using Schlenk techniques either in vacuum-line system or in an inertatmosphere glove box, except for the purification of the polymers, which were done in open air. Typical procedures for the polymerization are given below: Into a baked 20-mL Schlenk tube with a side arm was added $1 \mathrm{mmol}$ of the monomer. The tube was evacuated under vacuum and then flushed with dry nitrogen three times through the side arm. Three-milliliter dioxane was injected into the tube to dissolve the monomer. The catalyst solution was prepared in another tube by dissolving $4.6 \mathrm{mg}(0.01 \mathrm{mmol})[\mathrm{Rh}(\mathrm{nbd})$ $\mathrm{Cl}_{2}$ and $2.02 \mathrm{mg}(0.02 \mathrm{mmol}) \mathrm{Et}_{3} \mathrm{~N}$ in $2 \mathrm{~mL}$ dioxane, which was transferred to the monomer solution using a hypodermic syringe. The reaction mixture was stirred at $60^{\circ} \mathrm{C}$ under nitrogen for $6 \mathrm{~h}$. The mixture was then diluted with $5 \mathrm{~mL}$ 
dioxane and added dropwise to $200 \mathrm{~mL}$ methanol under stirring. The precipitate was centrifuged and redissolved in THF. The THF solution was added dropwise into $200 \mathrm{~mL}$ methanol to precipitate the polymer. The dissolutionprecipitation process was repeated three times, and the final precipitate was dried under vacuum at $40{ }^{\circ} \mathrm{C}$ to a constant weight.

\subsubsection{Poly(5-\{[(4'-nitro-4-azobenzene)oxy $]$ carbonyl $\}-1-$ pentyne) $P \mathbf{1}(3)$}

Red-brown powder; yield 68.9\%. $M_{\mathrm{w}} 31,200 ; M_{\mathrm{w}} / M_{\mathrm{n}}$ : 2.5 (GPC, polystyrene calibration; Table 1, No. 3). IR $(\mathrm{KBr}), \nu\left(\mathrm{cm}^{-1}\right): 3102(=\mathrm{C}-\mathrm{H}), 2930\left(\mathrm{CH}_{2}\right), 1761(\mathrm{C}=\mathrm{O})$, 1600 (Ar), 1522, 1348, $863\left(\mathrm{NO}_{2}\right) .{ }^{1} \mathrm{H}$ NMR $(300 \mathrm{MHz}$, $\left.\mathrm{CDCl}_{3}\right), \delta$ (ppm): 8.35, 7.96, 7.30 (br., Ar-H and trans $=\mathrm{C}-$ $\mathrm{H}), 2.74\left(2 \mathrm{H}\right.$, br., $\left.=\mathrm{CCH}_{2} \mathrm{CH}_{2} \mathrm{CH}_{2}\right), 2.39$ (2H, br., $=\mathrm{CCH}_{2-}$ $\mathrm{CH}_{2}$ ), $2.01\left(2 \mathrm{H}\right.$, br., $\left.=\mathrm{CCH}_{2} \mathrm{CH}_{2}\right)$.

\subsubsection{Poly(10-\{[(4'-nitro-4-azobenzene)oxy]carbonyl $\}-1$ - decyne) P1(8)}

Red-brown powder; yield 63.5\%. $M_{\mathrm{w}} 16,900 ; M_{\mathrm{w}} / M_{\mathrm{n}}$ : 2.4 (GPC, polystyrene calibration; Table 1, No. 6). IR $(\mathrm{KBr}), \nu\left(\mathrm{cm}^{-1}\right): 2930,2856\left(\mathrm{CH}_{2}\right), 1760(\mathrm{C}=\mathrm{O}), 1585(\mathrm{Ar})$, 1520, 1344, $852\left(\mathrm{NO}_{2}\right) .{ }^{1} \mathrm{H}$ NMR $\left(300 \mathrm{MHz}, \mathrm{CDCl}_{3}\right), \delta$ (ppm): 8.39, 8.01, 7.29 (br., Ar-H and trans $=\mathrm{C}-\mathrm{H}$ ), 2.60 $\left[2 \mathrm{H}\right.$, br., $\left.=\mathrm{CCH}_{2} \mathrm{CH}_{2}\left(\mathrm{CH}_{2}\right)_{4} \mathrm{CH}_{2} \mathrm{CH}_{2}\right], 2.27$ (2H, br., $\left.=\mathrm{CCH}_{2} \mathrm{CH}_{2}\right), 1.76\left[2 \mathrm{H}\right.$, br., $\left.=\mathrm{CCH}_{2} \mathrm{CH}_{2}\left(\mathrm{CH}_{2}\right)_{4} \mathrm{CH}_{2}\right], 1.58$ (2H, br., $\left.=\mathrm{CCH}_{2} \mathrm{CH}_{2}\right), 1.38\left[8 \mathrm{H}\right.$, br., $\left.=\mathrm{CCH}_{2} \mathrm{CH}_{2}\left(\mathrm{CH}_{2}\right)_{4}\right]$.

\subsubsection{Poly(5-\{[(4'-nitro-3-bromo-4-azobenzene $)$ oxy $]$ car- bonyl\}-1-pentyne) P2(3)}

Red-brown powder; yield 59.7\%. $M_{\mathrm{w}} 26,200 ; M_{\mathrm{w}} / M_{\mathrm{n}}: 2.1$ (GPC, polystyrene calibration; Table 1, No. 9). IR (KBr), $\nu$ $\left(\mathrm{cm}^{-1}\right): 3102(=\mathrm{C}-\mathrm{H}), 2930\left(\mathrm{CH}_{2}\right), 1761(\mathrm{C}=\mathrm{O}), 1600(\mathrm{Ar})$, $1523,1345,852\left(\mathrm{NO}_{2}\right) .{ }^{1} \mathrm{HNMR}\left(300 \mathrm{MHz}, \mathrm{CDCl}_{3}\right), \delta(\mathrm{ppm})$ : 8.34, 8.17, 7.96, 7.64, 7.30 (br., Ar-H and trans $=\mathrm{C}-\mathrm{H}$ ), 6.11 (br. cis $=\mathrm{C}-\mathrm{H}$ ), 2.75 (2H, br., $=\mathrm{CCH}_{2} \mathrm{CH}_{2} \mathrm{CH}_{2}$ ), 2.50 (2H, br., $\left.=\mathrm{CCH}_{2} \mathrm{CH}_{2}\right), 2.04\left(2 \mathrm{H}\right.$, br., $\left.=\mathrm{CCH}_{2} \mathrm{CH}_{2}\right)$.
2.4.4. Poly(10-\{[(4'-nitro-3-bromo-4-azobenzene)oxy]carbonyl\}-1-decyne) P2(8)

Red-brown powder; yield 55.4\%. $M_{\mathrm{w}} 18,700 ; M_{\mathrm{w}} / M_{\mathrm{n}}$ : 2.6 (GPC, polystyrene calibration; Table 1, No. 12). IR $(\mathrm{KBr}), \nu\left(\mathrm{cm}^{-1}\right): 2931,2853\left(\mathrm{CH}_{2}\right), 1757(\mathrm{C}=\mathrm{O}), 1596$ (Ar), 1528, 1345, $863\left(\mathrm{NO}_{2}\right) .{ }^{1} \mathrm{H} \mathrm{NMR}\left(300 \mathrm{MHz}, \mathrm{CDCl}_{3}\right)$, $\delta$ (ppm): 8.37, 8.22, 7.91, 7.29 (br., Ar-H and trans $=\mathrm{C}-\mathrm{H}$ ), 2.66 [2H, br., $\left.=\mathrm{CCH}_{2} \mathrm{CH}_{2}\left(\mathrm{CH}_{2}\right)_{4} \mathrm{CH}_{2} \mathrm{CH}_{2}\right], 2.21$ (2H, br., $\left.=\mathrm{CCH}_{2} \mathrm{CH}_{2}\right), 1.88$ [2H, br., $\left.=\mathrm{CCH}_{2} \mathrm{CH}_{2}\left(\mathrm{CH}_{2}\right)_{4} \mathrm{CH}_{2}\right], 1.55$ $\left(2 \mathrm{H}\right.$, br., $\left.=\mathrm{CCH}_{2} \mathrm{CH}_{2}\right), 1.38\left[8 \mathrm{H}\right.$, br., $\left.=\mathrm{CCH}_{2} \mathrm{CH}_{2}\left(\mathrm{CH}_{2}\right)_{4}\right]$.

\section{Results and discussion}

\subsection{Monomer synthesis}

We designed the molecular structures of four 1-alkyne derivatives containing azobenzene pendants and elaborated a two-step reaction route for their synthesis (Scheme 1). Diazotization of 4-nitroaniline with phenol or 2-bromophenol gives azobenzene derivatives S1 or S2. Respective esterification of S1 and S2 with alkynoic acids in the presence of 1,3-dicyclohexylcarbodiimide (DCC) and 4(dimethylamino)pyridine (DMAP) produces the pure monomers in $63-78 \%$ yields after purification by column and recrystallization. We characterized all the intermediates and monomers by standard spectroscopic methods and obtained satisfactory analysis data corresponding to their molecular structures.

\subsection{Polymerization reactions}

We first attempted to polymerize $\mathbf{1}(\mathrm{m})$ and $\mathbf{2}(\mathrm{m})$ by classic metathesis catalysts of $\mathrm{WCl}_{6}$ and $\mathrm{MoCl}_{5}$ but no polymeric products are obtained. The catalysts may be toxic by the polar azo groups in the monomers, leading to failure in the polymerization. Since organorhodium complexes are found to be tolerant of polar functional groups in the

Table 1

Polymerization of $\mathbf{1}(m)$ and $\mathbf{2}(m)$

\begin{tabular}{|c|c|c|c|c|c|}
\hline No. & Monomer & Temp. $\left({ }^{\circ} \mathrm{C}\right)$ & Yield (\%) & $M_{\mathrm{w}}^{\mathrm{a}}$ & $M_{\mathrm{w}} / M_{\mathrm{w}}{ }^{\mathrm{a}}$ \\
\hline 1 & 1(3) & 30 & 48.7 & 18,100 & 2.5 \\
\hline 2 & $\mathbf{1}(3)$ & 30 & 56.4 & 24,600 & 2.3 \\
\hline 3 & $\mathbf{1}(3)$ & 60 & 68.9 & 31,200 & 2.5 \\
\hline 4 & 1(3) & 90 & 64.5 & 27,800 & 2.6 \\
\hline 5 & $\mathbf{1}(8)$ & 30 & 7.8 & 8600 & 1.3 \\
\hline 6 & $\mathbf{1}(8)$ & 60 & 63.5 & 16,900 & 2.4 \\
\hline 7 & $\mathbf{1}(8)$ & 90 & 61.2 & 15,800 & 2.5 \\
\hline 8 & $2(3)$ & 30 & 50.4 & 33,100 & 2.8 \\
\hline 9 & $2(3)$ & 60 & 59.7 & 26,200 & 2.1 \\
\hline 10 & $2(3)$ & 90 & 54.9 & 27,400 & 2.6 \\
\hline 11 & $2(8)$ & 30 & 5.7 & 7200 & 1.3 \\
\hline 12 & $2(8)$ & 60 & 55.4 & 18,700 & 2.6 \\
\hline 13 & $2(8)$ & 90 & 47.8 & 15,900 & 2.3 \\
\hline
\end{tabular}

Polymerization catalyzed by $[\mathrm{Rh}(\mathrm{nbd}) \mathrm{Cl}]_{2}-\mathrm{Et}_{3} \mathrm{~N}$ in THF (No. 1) or dioxane (No. 2-13) for $24 \mathrm{~h}$.

${ }^{a}$ Estimated by GPC on the basis of a polystyrene calibration. 
acetylenes, we thus tried to polymerize the monomers using $[\mathrm{Rh}(\mathrm{nbd}) \mathrm{Cl}]_{2}-\mathrm{Et}_{3} \mathrm{~N}$ as catalyst [16]. Polymerization of $\mathbf{1}(3)$ in THF at $30^{\circ} \mathrm{C}$ gives a polymer with an $M_{\mathrm{w}}$ of $1.8 \times 10^{4} \mathrm{Da}$ in a moderate yield (Table 1, No. 1). Changing the solvent to dioxane increases the yield and molecular weight, which become even higher when the polymerization is conducted at elevated temperatures. Unlike 1(3), the reaction of 1(8) at $30{ }^{\circ} \mathrm{C}$ only produces a trace amount of polymeric product. Increasing the polymerization temperature, however, has dramatically activated the catalyst and completely soluble polymers are obtained in over $60 \%$ yield.

The polymerization behaviors of $2(3)$ are similar to those of 1(3) and the reaction conducted in dioxane gives high molecular weight polymers in satisfactory yields, irrespective of the polymerization temperature. Similar to $\mathbf{1}(8)$, the polymerization of $2(8)$ carried out at $30{ }^{\circ} \mathrm{C}$ produces only a polymer in a low yield. The yield and molecular weight, however, are boosted more than 7- and 2 -folds, respectively, when the polymerization is performed at high temperatures.

\subsection{Structural characterization}

All the purified polymers give satisfactory spectroscopic data corresponding to their expected molecular structures (Section 2 for details). An example of the IR spectra of monomer 1(3) and its polymer P1(3) are given in Fig. 1. Monomer 1(3) exhibits characteristic $\equiv \mathrm{C}-\mathrm{H}$ and $\mathrm{C} \equiv \mathrm{C}$ stretching vibrations at 3277 and $2127 \mathrm{~cm}^{-1}$, respectively, which completely disappear in the spectrum of its polymer P1(3), suggesting that the triple bond of the 1(3) has been converted to double bond polyacetylene backbone of P1(3).

The ${ }^{1} \mathrm{H}$ NMR spectra of $\mathrm{P} 1(m)$ and $\mathrm{P} 2(m)$ are shown in Fig. 2. The spectrum of P2(3) shows no acetylene proton of 2(3) at $\delta 2.05 \mathrm{ppm}$. On the other hand, a new broad resonance peak corresponding to the cis-olefin proton absorption is observed at $\delta 6.11 \mathrm{ppm}$. The absorption of the propargyl proton at $\delta 2.41 \mathrm{ppm}$ also becomes broadened

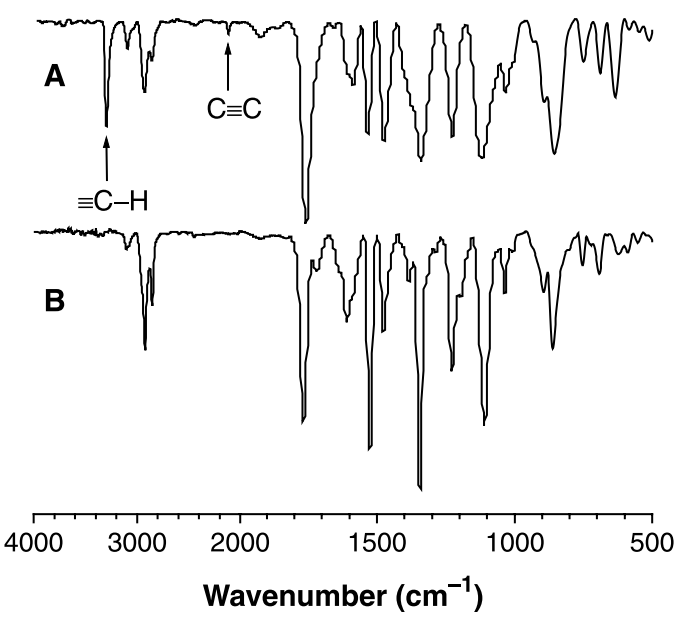

Fig. 1. IR spectra of (A) 1(3) and (B) its polymer P1(3).

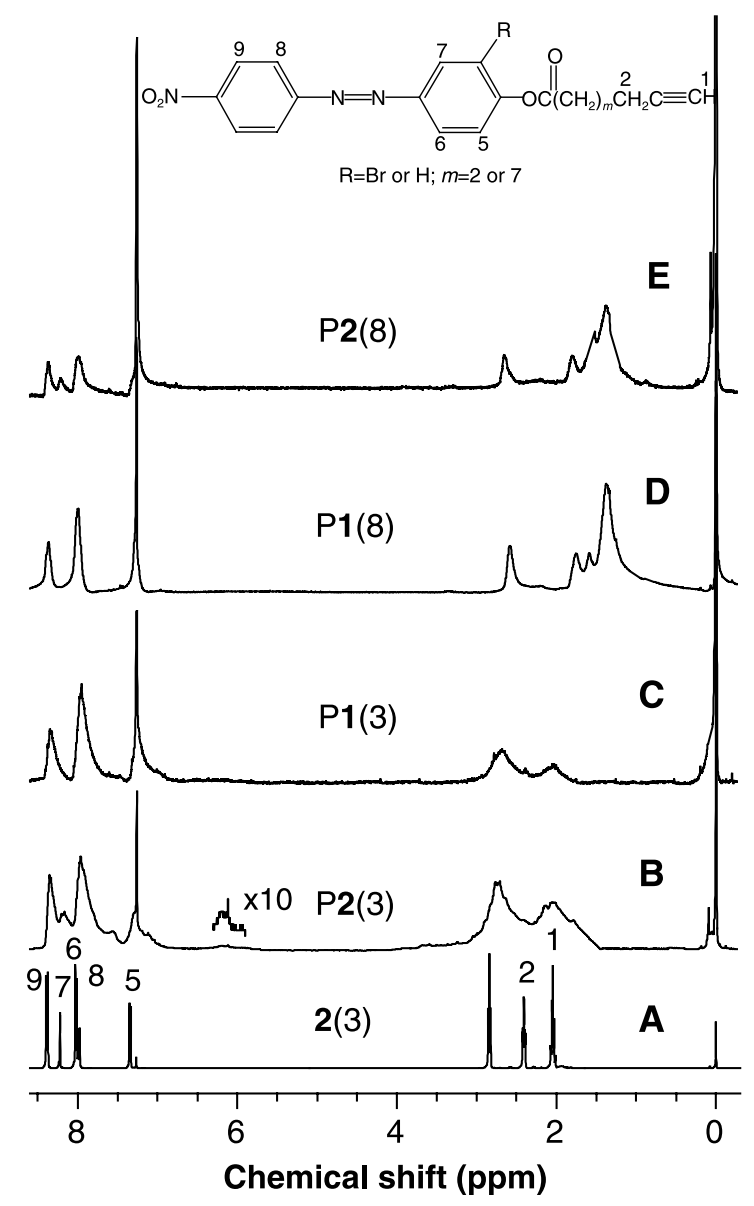

Fig. 2. ${ }^{1} \mathrm{H}$ NMR spectra of (A) monomer 2(3) and polymers (B) P2(3), (C) $\mathrm{P1}$ (3), (D) P1(8), and (E) P2(8) in chloroform- $d$ (samples taken from Table 1, No. 3, 6, 9, and 12).

upon polymerization owing to its transformation to the allylic structure by the acetylene polymerization [17]. The cis-content of P2(3) is calculated to be $14.8 \%$ based on the method reported by Simionescu and Tang [18,19], Other polymers also give satisfactory analysis data corresponding to their molecular structures. No absorptions are found in the olefin absorption region of $\delta 5.8-6.0 \mathrm{ppm}$, suggesting that these polymers possess predominantly transconfigurations.

The UV spectra of the polymers in chloroform are shown in Fig. 3. P1(3) exhibits two absorption peaks at 240 and $340 \mathrm{~nm}$ associated with corresponding the $\pi-\pi^{*}$ transitions of the phenyl and azobenzene chromophores, respectively. The backbone absorption is found at wavelengths longer than $400 \mathrm{~nm}$ and well extends to $600 \mathrm{~nm}$ with low intensities. The steric effect of the bulky azobenzene pendants may force the double bonds of the polyacetylene main chains out of planarity, leading to low absorptivity. The ground state electronic transitions of the polymers are not affected by the spacer length and the substitutent on the azobenzene ring: The UV profiles of P1(8), P2(3), and P2(8) are practically the same to that of $\mathrm{P} \mathbf{1}(3)$. 


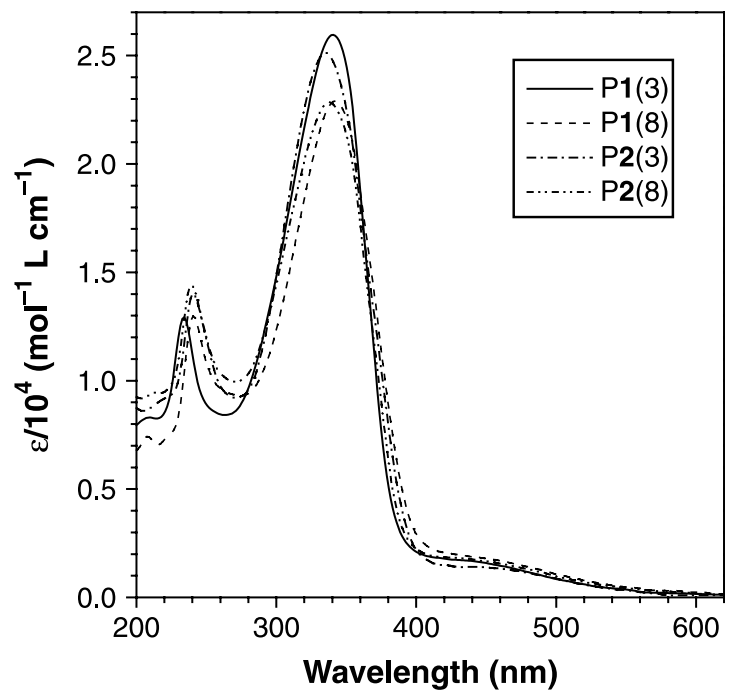

Fig. 3. UV spectra of chloroform solutions of P1(3), P1(8), P2(3), and P2(8) (samples taken from Table 1, No. 3, 6, 9, and 12).

\subsection{Thermal properties}

The poly(1-alkynes) such as poly(1-butyne) and poly(1hexyne), which may be regarded as the parent forms of P1 $(m)$ and P2 $(m)$, are so unstable that even the isolation process of the polymer products from the polymerization reactions leads to degradation [20,21]. Thus, the initially precipitated poly(1alkyne) products in methanol are white and fibrous; they change to yellow powders after drying under vacuum. Poly(1hexyne) starts to lose its weight at $150{ }^{\circ} \mathrm{C}$, and heating for a few minutes at the temperature easily changes the yellow powder to a brown gummy fluid [21]. On the other hand, except for the polymerization reactions, which were carried out under an atmosphere of dry nitrogen, all the handlings, including the isolation, purification, and storage of $\mathrm{P} 1(m)$ and $\mathrm{P} 2(m)$, were done in an open atmosphere, during which no any changes in the color and form of the polymer products were observed. As shown in Fig. 4, all the polymers decompose at a temperature as high as $270{ }^{\circ} \mathrm{C}$, irrespective of the spacer length and substitutent on the azobenzene ring. Thus, the incorporation of the rigid azobenzene group into poly(1-alkynes) had endowed the polymers with high thermal stability. The thermal stability enhancement of $\mathrm{P} 1(\mathrm{~m})$ and $\mathrm{P} 2(\mathrm{~m})$ may be due to the 'jacket effect' of the aromatic azobenzene pendants. That is, the alternating-double-bond backbone of the polymers is surrounded by a rigid 'jacket' formed through the strong intra- and interchain molecular electronic interaction of the polarized aromatic azobenzene groups, shielding the polymer main chains from the thermal attack. Similar results are also found by Masuda, Tang and our previous work [16,17,22-25], respectively.

\subsection{Optical limiting property}

Fig. 5 shows the optical limiting performances of P1(8) in THF with different concentrations. The transmitted

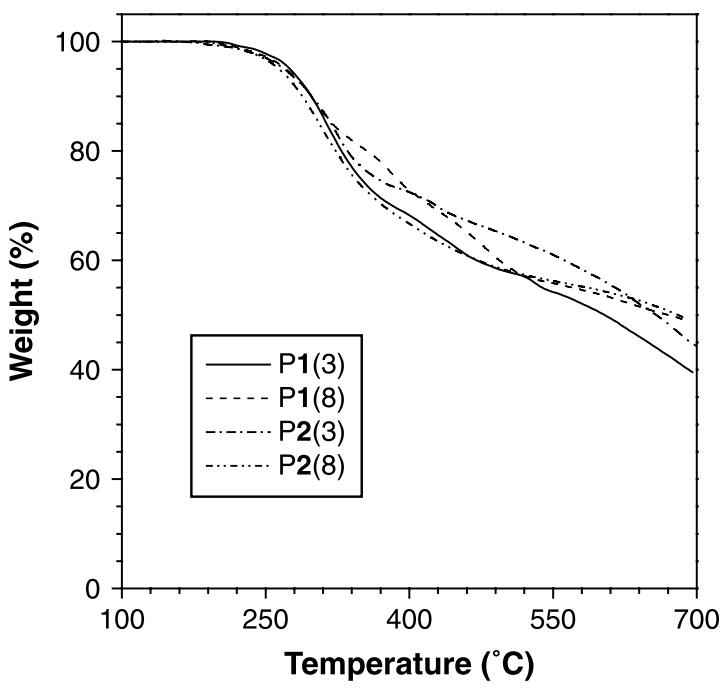

Fig. 4. TGA thermograms of P1(3), P1(8), P2(3), and P2(8) (samples taken from Table 1 , No. 3, 6, 9, and 12) recorded under nitrogen at a heating rate of $20^{\circ} \mathrm{C} / \mathrm{min}$.

fluence of all the solutions increases linearly with the incident fluence at low fluence region but starts to depart and reaches a plateau at high incident fluence. In our optical limiting experiment, we investigated the photostability of P1(8) by three repeated experiments, finding that the optical limiting properties of P1(8) are rather stability. Simultaneously, we also checked the FT-IR and UV-vis spectrum of P1(8) before and after the laser irradiation in our optical limiting experiment and found that the FT-IR and UV-vis absorption spectra of FTIR and UV-vis absorption spectra did not change, hinting that the P1(8) possesses good photostability. In contrast, the transmittance of the poly(PA) solution continually increase instead of decrease due to the laser-induced photolysis of the polyacetylene chains [26],

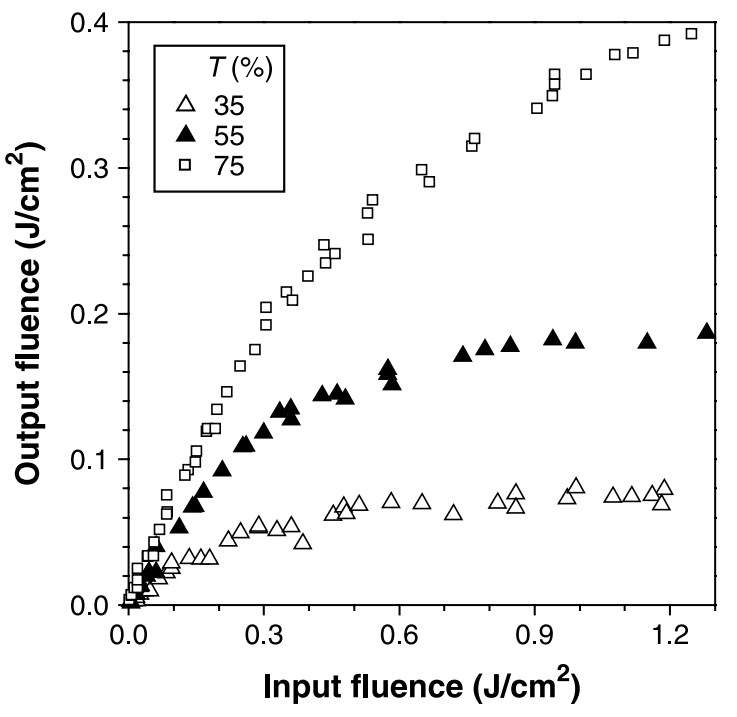

Fig. 5. Optical responses to $8 \mathrm{~ns}, 1 \mathrm{~Hz}$ pulses of $532 \mathrm{~nm}$ laser light of THF solutions of P2(3) (sample taken from Table 1, No. 6) with different linear transmittances. 
indicating that the incorporation of azobenzene makes polyacetylene to be endowed with a new optical propertyoptical limiting property and good photostability. Furthermore, the light limitation is affected by the concentration and becomes better in solutions with high concentrations. For example, the limiting threshold (incident fluence at which the output fluence starts to deviate from linearity) and limiting amplitude (the maximum output intensity) of the sample vary from 0.166 to 0.095 and $0.180-0.070 \mathrm{~J} / \mathrm{cm}^{2}$, respectively, when the solution concentration increases from $0.46(T=55 \%)$ to $0.83 \mathrm{mg} / \mathrm{mL}(T=35 \%)$. Similar results are also found by Kojima and our previous publications [26-31]. Solutions with higher concentrations have more molecules per unit volume, which should be able to absorb the energy of harsh laser light more efficiently. On the contrary, the optical limiting performances of the polymers become poorer when the solution is diluted. For example, the limiting threshold of the sample changes from 0.166 to $0.245 \mathrm{~J} / \mathrm{cm}^{2}$ when the solution concentration decreases from $0.46(T=55 \%)$ to $0.21 \mathrm{mg} / \mathrm{mL}(T=75 \%)$.

Fig. 6 shows the optical limiting properties of the polymers at the same linear transmittance $(T=75 \%)$ and the results are summarized in Table 2. All the polymers are good optical limiters, especially for those with short spacer lengths. For example, the limiting threshold and limiting amplitude of P1(3) are 0.245 and $0.349 \mathrm{~J} / \mathrm{cm}^{2}$, respectively, which are 1.3 and 1.2 times lower than those of P1(8). The optical limiting properties are also influenced by the ring substitutent and become poorer in polymers with bromine functionalities on the azobenzene pendants, as suggested by the higher limiting threshold $\left(0.295 \mathrm{~J} / \mathrm{cm}^{2}\right)$ and limiting amplitude $\left(0.393 \mathrm{~J} / \mathrm{cm}^{2}\right)$ of $\mathrm{P} 2(3)$ than $\mathrm{P} 1(3)$.

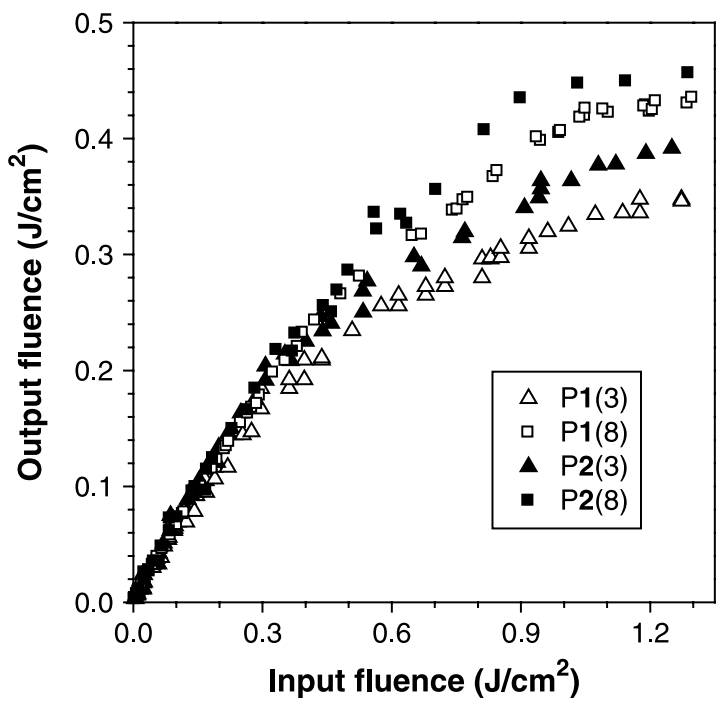

Fig. 6. Optical responses to $8 \mathrm{~ns}, 1 \mathrm{~Hz}$ pulses of $532 \mathrm{~nm}$ laser light of THF solutions of P1(3), P1(8), P2(3), and P2(8) (samples taken from Table 1, No. 3, 6, 9, and 12) with a linear transmission of $75 \%$.

\subsection{Nonlinear optical property}

The nonlinear absorption coefficients of the polymers are measured by $\mathrm{Z}$ scan technique. The results of $\mathrm{Z}$ scan with and without an aperture show that all the polymers have both nonlinear absorption and refraction. Thus, the $\chi^{(3)}$ of the polymers should be dual attributed to nonlinear absorption $\left(\alpha_{2}\right)$ of and refractive $\left(n_{2}\right)$ of the molecules. The Z scan results of P2(3) are shown exemplarily in Fig. 7.

In theory, the normalized transmittance for the open aperture can be written as $[15,32]$

$T(z, s=1)=\sum_{m=0}^{\infty} \frac{\left[-q_{0}(z)\right]^{m}}{(m+1)^{3 / 2}}, \quad$ for $\left|q_{0}\right|<1$

where $q_{0}(z)=\alpha_{2} I_{0}(t) L_{\text {eff }} /\left(1+z^{2} / z_{0}^{2}\right)$ with $\alpha_{2}$, nonlinear absorption coefficient; $I_{0}(t)$, intensity of laser beam at focus $(z=0) ; L_{\text {eff }}=\left[1-\exp \left(-\alpha_{0} L\right)\right] / \alpha_{0}=$ effective thickness with $\alpha_{0}$, linear absorption coefficient; $L$, sample thickness; $z_{0}$, diffraction length of the beam, and $z$, sample position. Thus, the nonlinear absorption coefficients of the polymers can be determined by fitting the experimental data using Eq. (1).

The nonlinear refractive index $n_{2}$ is given by $[15,32]$

$n_{2}=\frac{\lambda \alpha_{0}}{2 \pi I_{0}\left(1-\mathrm{e}^{-\alpha_{0} L}\right)} \frac{\Delta T_{\mathrm{p}-\mathrm{v}}}{0.416(1-S)^{0.25}}$

where $\Delta T_{\mathrm{p}-\mathrm{v}}$ is the difference between the normalized transmittance values at the valley and peak portions and $S$ is the aperture size $(S=0.12)$. Thus, the nonlinear refractive coefficients of the polymers can be determined by using Eq. (2). 30]

The $\chi^{(3)}$ can be calculated by the following equation [15,

$$
\left|\chi^{(3)}\right|=\sqrt{\left|\frac{c n_{0}^{2}}{80 \pi} n_{2}\right|^{2}+\left|\frac{9 \times 10^{8} \varepsilon_{0} n_{0}^{2} c^{2}}{4 \pi \omega} \alpha_{2}\right|^{2}}
$$

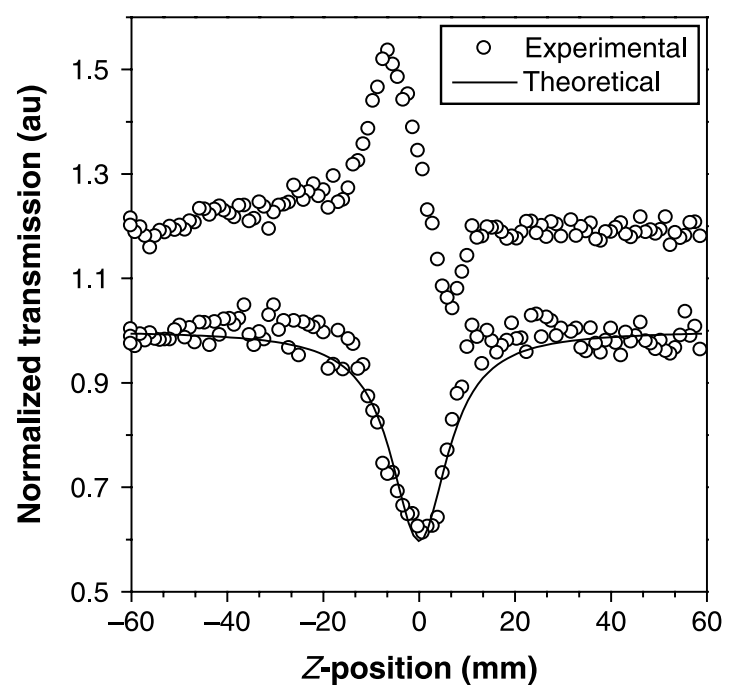

Fig. 7. Z scan data of $\mathrm{P2}$ (3) (sample taken from Table 1, No. 6) in THF. 
Table 2

Properties of the polymers

\begin{tabular}{|c|c|c|c|c|c|c|}
\hline \multirow[t]{2}{*}{ Polymer } & \multirow{2}{*}{$\begin{array}{l}\text { Thermal stability } \\
T_{\mathrm{d}}\left({ }^{\circ} \mathrm{C}\right)\end{array}$} & \multirow{2}{*}{$\begin{array}{l}\text { Limiting threshold } \\
\left(\mathrm{J} / \mathrm{cm}^{2}\right)\end{array}$} & \multirow{2}{*}{$\begin{array}{l}\text { Limiting amplitude }{ }^{\mathrm{c}} \\
\left(\mathrm{J} / \mathrm{cm}^{2}\right)\end{array}$} & \multicolumn{3}{|c|}{ Nonlinear optical values ${ }^{\mathrm{d}}$} \\
\hline & & & & $\overline{\alpha_{2}(\mathrm{~m} / \mathrm{W})}$ & $n_{2}\left(\mathrm{~m}^{2} / \mathrm{W}\right)$ & $\chi^{(3)}(\mathrm{esu})$ \\
\hline $\mathrm{P} 1(3)$ & 275 & 0.245 & 0.349 & $5.36 \times 10^{-10}$ & $5.68 \times 10^{-17}$ & $1.43 \times 10^{-10}$ \\
\hline P1(8) & 263 & 0.322 & 0.429 & $4.70 \times 10^{-10}$ & $4.54 \times 10^{-17}$ & $1.15 \times 10^{-10}$ \\
\hline $\mathrm{P} 2(3)$ & 268 & 0.295 & 0.393 & $4.69 \times 10^{-10}$ & $5.09 \times 10^{-17}$ & $1.22 \times 10^{-10}$ \\
\hline $\mathrm{P} 2(8)$ & 271 & 0.344 & 0.450 & $4.12 \times 10^{-10}$ & $3.07 \times 10^{-17}$ & $7.78 \times 10^{-11}$ \\
\hline
\end{tabular}

a Temperature for $5 \%$ weight loss.

b Incident fluence at which the output fluence starts to deviate from linearity.

c Maximum output intensity.

d Measured by $\mathrm{Z}$ scan technique with an $8 \mathrm{~ns} \mathrm{Nd:YAG} \mathrm{laser} \mathrm{system} \mathrm{at} 1 \mathrm{~Hz}$ repetition rate and $532 \mathrm{~nm}$ wavelength.

where $\varepsilon_{0}$, permittivity of vacuum; $c$, speed of light; $n_{0}$, refractive index of the medium, and $\omega=2 \pi c / \lambda$. The calculation results of the nonlinear optical coefficients of the four polymers are shown in Table 2. From Table 2, we can see that the nonlinear susceptibilities of all the polymers are as high as $\sim 10^{-10}$ esu, which are almost three orders of magnitude larger than those of poly(phenylacetylene) $[8,9$, $33,34]$, and larger than poly ( $N$-carbazolyacetylene) [10], poly(1-naphtylacetylene) [11], and the copolymer of 1-naphthylacetylene and 9-anthrylacetylene [11], respectively. Thus, the attachment of azobenzene moieties into the polyacetylene main chain has enhanced the nonlinear optical properties of polyacetylenes significantly. Simultaneously, we also found from Table 2 that the nonlinear susceptibility of polymers are lower with increasing spacer lengths or bromine substitutent on the azobenzene rings. This result is similar to the results obtained from optical limiting analysis.

\section{Conclusions}

Functional polyacetylenes containing azobenzene pendants are synthesized in satisfactory yields by $[\mathrm{Rh}(\mathrm{nbd}) \mathrm{Cl}]-$ $\mathrm{Et}_{3} \mathrm{~N}$ catalyst. All the polymers are soluble in common organic solvents such as $\mathrm{CHCl}_{3}$ and THF and possess high thermal stability. Their optical limiting and nonlinear optical properties are investigated by an $8 \mathrm{~ns} \mathrm{Nd}$ :YAG laser system at $532 \mathrm{~nm}$ wavelength. Results show that the optical limiting and nonlinear optical performances are affected by the spacer length and ring substitutent, with polymers having longer spacer lengths and bromine functionality on the azobenzene ring show inferior properties.

\section{Acknowledgements}

This research was financially supported by the National Natural Science Fund of China (Grant Nos. 90206014 and 50472038), Program for New Century Excellent Talents in University (NCET-04-0588), the Outstanding Youth Fund of Anhui Province (Grant No. 04044060), and the Award for High Level Intellectuals (Grant No. 2004Z027) from Anhui Province.

\section{References}

[1] Tutt LW, Kost A. Nature 1992;356:225.

[2] Tutt LW, Boggess TF. Prog Quantum Electron 1993;17:299.

[3] Qureshi FM, Martin SJ, Long X, Bradley DDC, Henari FZ, Blau WJ, et al. Chem Phys 1998;231:87.

[4] Kuebler SM, Denning RG, Anderson HL. J Am Chem Soc 2000;122: 339.

[5] Zhou GJ, Zhang S, Wu PJ, Ye C. Chem Phys Lett 2002;363:610.

[6] Fann WS, Benson S, Madey JM, Etemad S, Baker GL, Kajar F. Phys Rev Lett 1989;62:1492.

[7] Sone T, Asako R, Masuda T, Tabata M, Wada T, Sasabe H. Macromolecules 2001;34:1586.

[8] Nehert D, Kaltbeitzelz A, Wolf A, Bubeck C, Wegner G. J Phys D: Appl Phys 1991;24:1193.

[9] Wada T, Wang L, Okawa H, Masuda T, Tabata M, Wan M, et al. Mol Cryst Liq Cryst 1997;294:245.

[10] Sata T, Nomura R, Wada T, Sasabe H, Masuda T. J Polym Sci, Part A: Polym Chem 1998;36:2489.

[11] Nanjo K, Karim SMA, Nomura R, Wada T, Sasabe H, Masuda T. J Polym Sci, Part A: Polym Chem 1999;37:277.

[12] Nomura R, Karim SMA, Kajii H, Hidayat R, Yoshino K, Masuda T. Macromolecules 2000;33:4313.

[13] Schuling A. Chem Phys Lett 1967;1:195.

[14] Qu SL, Song YL, Du CM, Wang YX, Gao YC, Liu ST, et al. Opt Commun 2001;196:317.

[15] BaHae MS, Said AA, Wei TH, Hagan DJ, Stryland EWV. IEEE J Quantum Electron 1990;26:760.

[16] Terguchi M, Masuda T. Macromolecules 2000;33:240.

[17] Lam JWY, Dong YP, Cheuk KKL, Luo JD, Xie ZL, Kwok HS, et al. Macromolecules 2002;35:1229.

[18] Simionescu CI, Percec V. J Polym Sci, Polym Symp 1980;67:43.

[19] Tang BZ, Poon WH, Leung SM, Leung WH, Peng H. Macromolecules 1997;30:2209.

[20] Masuda T, Okano Y, Tamura K, Higashimura T. Polymer 1985;26: 793.

[21] Masuda T, Tang BZ, Higashimura T, Yamaoka H. Macromolecules 1985;18:2369.

[22] Tang BZ, Kong XX, Wan XH, Feng XD. Macromolecules 1997;30: 5620.

[23] Tang BZ, Kong XX, Wan XH, Peng H, Lam JWY. Macromolecules 1998;31:2419.

[24] Yin SC, Xu HY, Shi WF, Gao YC, Song YL, Lam JWY, et al. Polymer 2005;46:7670. 
[25] Yin SC, Xu HY, Fang M, Shi WF, Gao YC, Song YL. Macromol Chem Phys 2005;206:1549.

[26] Tang BZ, Xu HY. Macromolecules 1999;32:2569.

[27] Kojima Y, Matsuoka T, Sato N, Takahashi H. Macromolecules 1995; 28:2893.

[28] Tang BZ, Xu HY, Lam JWY, Lee PPS, Xu KT, Sun QH, et al. Chem Mater 2000;12:1446.

[29] Xu HY, Sun QH, Lee PPS, Kwok HS, Tang BZ. Thin Solid Films 2000;363:143.
[30] Peng H, Cheng L, Luo JD, Xu KT, Sun QH, Dong YP, et al. Macromolecules 2002;35:5349.

[31] Chen JW, Peng H, Law CCW, Dong YP, Lam JWY, Williams ID, et al. Macromolecules 2003;36:4319.

[32] Zhang C, Song YL, Wang X, Kühn FE, Wang YX, Fun HK, et al. J Mater Chem 2002;12:239.

[33] Wada T, Masuda T, Sasabe H. Mol Cryst Liq Cryst 1994;247:139.

[34] Falconieri M, D’Amato R, Furlani A, Russo MV. Synth Met 2001; 124:217. 